\title{
PENINGKATAN MUTU PENDIDIKAN PONDOK PESANTREN MELALUI TOTAL QUALITY SERVICE
}

\author{
Oleh: \\ Arfandi \\ Universitas Ibrahimy Situbondo, Indonesia \\ arfandi.1985@gmail.com
}

\begin{abstract}
:
One of the quality management concepts that can be applied in pesantren is total quality service (TQS). Total Quality Service is a modern management concept of study that focuses of five areas, 1) customer focus, 2) total involvement, 3) measurement, 4) systematic support, and 5) connous improvement. Pesantren education institute is said quality meaning refers on resulting product quality by pesantren, one that covers; a lot of it student that have achievement well at akademik area and also at non academic, mark sense good lead support among pesantren "its customer", out put and out came pesantren corresponds to expectation, and is still a lot of again. Pesantren education quality in perspektif this, can also be seen of two things, which is points on education process and education result. Process quality education pointed out by components exhaustive involvement pesantren in education activity. Education result can be seen of insofar which pesantren grad have interest and personality corresponds to pesantren vision and mission.
\end{abstract}

Keyword: Mutu, Pendidikan, Pondok Pesantren, Total Quality Service

\section{A. Pendahuluan}

Pondok pesantren merupakan lembaga pendidikan Islam tradisional yang aktivitasnya adalah mempelajari, memahami, mendalami, menghayati, dan mengamalkan ajaran Islam dengan menekankan pada pentingnya moral keagamaan sebagai pedoman perilaku sehari-hari. ${ }^{1}$ Segalah aktivitasnya pun mendapat apresiasi penuh dari masyarkat sekitarnya. ${ }^{2}$

Kehadiran pondok pesantren di tengah-tengah masyarakat pada awalnya tidak hanya sebagai lembaga pendidikan saja, tetapi juga sebagai lembaga penyiar agama Islam. Pondok pesantren memiliki banyak kelebihan dan keunikan dibandingkan dengan lembaga pendidikan formal.

${ }^{1}$ Mastuhu, Dinamika Sistem Pendidikan Pesantren, (Jakarta: INIS, 1994), 55.

2 Samsul Nizar, Sejarah Pendidikan Isla : Menelusuri Jejak Sejarah Pendidikan Era Rasulullah sampai Indonesia, (Jakarta: Kencana, 2007), 286. 
Pondok pesantren merupakan satu-satunya lembaga pendidikan di Indonesia untuk tafaqquh fiddien, memahami manusia dalam urusan agama. Pendidikan agama dilakukan seutuhnya dalam segala aspek kehidupan, sehingga para kyai tidak hanya mencerdaskann para santrinya tetapi juga mendidik moral dan spritual ${ }^{3}$.

Seiring dengan perkembangan globalisasi, kecendrungan masyarakat terhadap pendidikan pesantren telah berubah, padahal out put pesantren tidak banyak berubah. Pokok permasalahannya bukan terletak pada potensi santri lulusan pesantren yang tidak pandai, melainkan pergeseran ukuran. Saat ini, yang menjadi ukuran dalam masyarakat adalah masalah yang menyangkut wawasan sosial, organiasasi modern, pluralisme keilmuan, pangsa pasar dan lain sebagainya. Masalahmasalah ini pada masa lampau tidak pernah diperhitungkan sama sekali dalam materi pendidikan pesantren. Kini pesantren menghadapi tantangan baru, yaitu tantangan pembangunan, kemajuan, pembaharuan, serta tantangan keterbukaan dan globalisasi.

Oleh karena itu, disadari bahwa perjuangan untuk menjadikan lembaga pendidikan Islam, khususnya pesantren, tetap eksis, survive, competetif, dan sesuai dengan market demand, tentunya membutuhkan sentuhan manajemen tepat guna. Salah satu konsep manajemn yang mampu meningkatkan mutu pendidikan pesantren tersebut adalah Total Quality Service. Melalui konsep manajemen ini diharapkan kesadaran masyarakat untuk memasukkan putra putrinya ke lembaga pendidikan pesantren semakin tinggi ${ }^{4}$, sehingga pesantren benar-benar menjadi parental choice bagi keberlangsungan pendidikan anak-anaknya.

\section{B. Pendidikan Pondok Pesantren}

\section{Pengertian Pondok Pesantren}

Istilah Pondok pesantren berasal dari pengertian asrama-asrama para santri yang disebut pondok atau tempat tinggal yang dibuat dari bambu atau berasal dari bahasa Arab fundug, yang berarti hotel atau asrama. ${ }^{5}$ Sedangkan perkataan peantren berasal dari kata santri ${ }^{6}$ dengan

${ }^{3}$ M.Sulton Masyhud dan Moh. Khusnurridlo, Manajemen Pondok Pesantren (Jakarta: Diva Pustaka, 2003), . 3.

4 Baharuddi, Pengembangan Lembaga Pendidikan Islam, (Malang UIN Maliki Press, 2011), . 89

5 Zamakhsari Dhofir, Tradisi Pesantren; Studi Pandangan Hidup Kiyai (Jakarta: LP3S, 1994), 18

6 Dalam Penelitiannya, Clifford Geertz berpendapat, kata santri mempunyai arti luas dan sempit. Dalam arti luas dan sempit santri adalah seorang murid satu sekolah

$240 \mid$ JURNAL LISAN AL-HAL 
awalan pe- dan akhiran -an yang berarti tempat para santri. Sedangkan menurut Nurcholis Madjid terdapat dua pendapat tentang arti kata "santri" tersebut. Pertama, pendapat yang mengatakan berasal dari kata "shantri", yaitu sebuah kata sanskerta yang berarti melek huruf. Kedua, pendapat yang mengatakan bahwa kata tersebut berasal dari bahasa jawa "cantrik" yang berarti seseorang yang selalu mengikuti seorang guru kemanapun guru itu pergi menetap. ${ }^{7}$ Nama "pesantren" sering kali dikaitkan dengan kata "santri" yan mirip dengan bahasa India "shantri" yang berarti orang yang mengetahui buku-buku suci agama Hindu atau orang yang ali tentang kitab suci. ${ }^{8}$

Selanjutnya kata pondok dan pesantren digabung menjadi satu sehingga membentuk pondok pesantren. Pondok pesantren menurut Arifin adalah suatu lembaga pendidikan agama Islam yang tumbuh serta diakui oleh masyarakat sekitar dengan system asarama (komplek) dimana santri-santri menerima pendidikan agama Islam melalui system pengajian atau madrasah yang sepenuhnya berada di bawah kedaulatan dari leadership seorang atau beberapa orang kiai dengan ciri-ciri khas yang bersifat karismatik serta independent dalam segala hal. ${ }^{9}$

Sedangkan menurut Zuhairini memberikan definisi mengenai pondok pesantren adalah tempat murid-murid (disebut santri) mengaji agama Islam dan sekaligus diasramakan di tempat itu. ${ }^{10}$ Pada dasarnya pesantren sebgai perwujudan dari dua keinginan yang bertemu. Keinginan orang-orang yang ingin menimba ilmu sebagai bekal idup (santri) dan keinginan orang yang secara ikhlas mengajarkan ilmu dan pengalamannya kepada umat (kiai). Sehingga secara fisik pondok pesantren adalah lembaga yang memadukan dua keinginan tersebut. Dalam pondok pesantren terdapat santri yang tidak menginap di pindok atau asrama, namun mereka pulang dan setiap aktu mulai mengaji mereka sudah siap. Mereka dinamakn santri desa atau santri kalong.

Pondok pesantren awal mulanya diidentifikasi sebagai "gejala desa". Gejala desa artinya pondok pesantren merupakan institusi

agama yang disebut pondok atau pesantren. Lihat Clifford Geertz, Abangan Santri, Priyayi dalam Masyarakat Jawa, ter. Aswab Mahasin (Jakarta: Dunia Pustaka Jaya/ 1983), 268.

${ }^{7}$ Nurcholis Madjid, Bilik-Bilik Pesantren, (Jakarta: Paramadina, 2006), 21.

8 Fuad Jabali dan Jamhari, IAIN dan Modernisasi Islam Di Indonesia, (Jakarta: Logos Wacana Ilmu, 2002), 94.

9 M. Arifin, Kapita Selekta Pendidikan (Islam dan Umum), (Jakarta: Bumi Aksara, 1991), 240.

${ }_{10}$ Zuhairini, Sejarah Pendidian Islam, (Jakarta: Bumi Aksara, 1992), 212. 
pendidikan Islam tradisional yang keadirannya bukan untuk menyiapkan pemenuhan tenaga kerja (skilled) atau profesional sebagaimana tuntutan masyarkat modern sekarang ini. ${ }^{11}$

\section{Tipologi Pesantren}

Pengertian pesantren, secara sederhana, dikemukakakn oleh Zamahsyari Dhofier dalam bukunya yang berudul Tradisi Pesantren. Ia mendefinisikan pesantren sebagai lembaga pendidikan tradisional Islam untuk mempelajari, memahami, menghayati dan mengamalkan ajaran Islam dengan menekankan pentingnya moral keagamaan sebagai pedoman perilaku sehari-hari. ${ }^{12}$ Syistem pendidikan pesantren menggunakan pendekatan holistic, artinya para pengasuh pesantren memandang bahwa kegiatan belajar mengajar merupakan kesatupaduan atau lebur dalam totalitas hidup sehari-hari. Bagi warga pesantren, belajar di pesantren tidak mengenal hitungan waktu (full time), kapan harus memulai kapan harus selesai, dan target apa yang harus dicapai. Idealnya pengembangan keperibadian yang dituju ialah keperibadian muslim kaffah, bukan sekadar Muslim biasa. ${ }^{13}$

Secara garis besar, karakter utama pesantren adalah, (1). Pesantren didirikan sebagai bagian dan atas dukungan masyarakatnya sendiri, (2). Pesantren dalam penyelenggaraan pendidikannya menerapkan kesetaraan dan kesederhanaan santrinya, tidak membedakan status dan tingkat kekayaan orang tuanya, (3). Pesantren mengembangkan misi 'menghilangkan kebodohan' khususnya tafaquh fi al-din dan menyiarkan agama islam.

Secara umum tipologi pesantren dapat diklasiikasikan atas dua enis yaitu: pesantren Salafiah, dan pesantren khalafiah. Katagore pesantren Salafiyah adalah yang dikatagorekan sebagai pesantren tradisional yang hanya mengaarkan keagamaan dan lembaga pendidikan madrasah, sedangkan pesantren khalafiah yang dikatagorekan sebagai pesantren modern yang selain mengajarkan pengetauan keagamaan, madrasah, dan keterampilan praktis. ${ }^{14}$ Sebagai lembaga pendidikan, dakwah, sosial, dan budaya, pesanten telah memeberikan corak khas bagi arah pendidikan di Nusantara. Kehadirannya mengikuti perekembangan

\footnotetext{
11Mahpuddin Noor, Potret Dunia Pesantren: Lintasan Searah Perubahan dan Perkembangan Pondok Pesantren (Bandung: Humaniora, 2006), 19.

12 Zamahsyari Dafier, Tradisi Pesantren (Jakarta: LP3ES, 1994), 3.

13 Mastuhu, Dinamika Sistem Pendidikan Pesantren, (Jakarta: INIS, 1994), 57.

${ }^{14}$ Erma Fatmawati, Profil Pesantren Maasiswa (Yogyakarta: LkiS, 2015), 32.

$242 \mid$ JURNAL LISAN AL-HAL
} 
dinamika masyarakat, ia selalu tampil untuk menawab tantangan yang dihadapi oleh masyarakat sekitarnya, denagan demikian kehidupan pesantren selalu dinamis. ${ }^{15}$

Dari berbagai tingkat konsistensi dengan sistem lama dan keterpengaruhan oleh sistem modern, secara garis besar pondok pesantren dapat dikatagorekan ke dalam tiga bentuk yaitu a) pondok pesantren Salafiyah; b) Pondok pesantren khalafiyah, dan c) Pondok pesantren campuran/kombinasi, ${ }^{16}$ serta jenis inovasi baru yang disebut sebagai pesantren mahasiswa.

a. Pesantren Salafiyah

Sesuai dengan namanya, Salaf yang berarti lama, pesantren Salafiyah adalah pondok pesantren yang menyelenggarakan pemebelajaran dengan pendekatan tradisional, sebagaimana yang berlangsung sejak aal pertumbuannya. Pesantren Salafiyah adalah pesantren yang menyelenggarakan pendidikan dengan menggunakan kitab kuning dan sistem pengajaran yang diterapakan oleh kiai atau pengasuh. ${ }^{17}$

b. Pesantren Khalafiyah

Khalaf berati 'kemudian' atau 'belakang' atau 'modern'. Sedangkan pesantren kalafiyah berarti pondok pesantren yang menyelenggarakan kegiatan pendidikan dengan pendekatan modern, melaui satuan pendidikan formal, baik Madrsah (MI, MTs, MA atau MAK), maupun sekolah/kampus. Pesantern khalaf menerima hal-hal yang baru yang dinilai baik disamping tetap memepertaankan tradisi lama yang baik. Pesantren jenis ini mengajarkan pelajaran umum di madrasah dengan sistem klasikal dan membuka sekolah/kampus umum di lingkungan pesantren. Dengan alasan itu, maka masyarakatnya menyebutnya dengan pesantren modern atau khalafiyah. ${ }^{18}$

c. Pesantren Campuran/Kombinasi

Sebagian besar yanag ada sekarang adalahh pondok pesantren yang berada diantara rentang dua pengertian di atas. Sebagian pondok pesantren yang mengaku atau yang menamakan diri dengan Salafiyah,

15 Hasan, Karakter dan Fungsi Pesantren dalam Dinamika Pesantren (Jakarta: P3M, 1998), 49.

16Depag RI Dirjen Kelembagaan Agama Islam, Pondok Pesantren dan Madrasah Diniyah Pertumbuhan dan Perkembangannya (Jakarta, DEPAG RI, 2003), 28-30.

17 Permenag RI Nomor 3 Tahun 2012 Tentang Pendidikan Keagamaan Islam Bab 1 Ketentuan Umum Ayat 5.

18 Yasmadi, Modernisasi Pseantren: Kritik Nourcholis Madjid terhadap Pendidikan Islam Tradisioanal (Jakarta: Ciputat Press, 2005), 70. 
umumnya juga menyelenggarakan secara klasikal dan berenjang, alaupun tidak dengan nama madrasah atau sekolah/kampus. Demikian juga pesantren khalafiyah yang pada mumnya uga mmenyelenggarakan pendidikan dengan pendekatan pengaian kitab klasik, karena sistem ngai kitab itulah yang selama ini diakui sebagai salah satu identitas pondok pesantren.

\section{Sistem Pendidikan dan Pengajaran di Pondok Pesantren}

Kata sistem mempunyai arti "susunan aturan, atau cara"19 untuk mencapai tujuan tertentu dimana dalam penggunaannya bergantung kepada berbagai faktor serta hubungannya dengan usaha pencapaian tujuan tersebut. Menurut M. Amien Rais, karakteristis yang di anggap unik dalam sistem pendidikan Pondok Pesantren, antara lain:

a. Dalam sistem pendidikan tradisional ini para santri mempunyai kebebasan yang lebih besar di banding murid-murid sekolah modern dalam bertindak dan berinisiatif, sebab hubungan antar kiai dan santri bersifat dua arah.

b. Kehidupan pesantren menanamkan hidup demokrasi di kalangan para santri, karena mereka praktis harus bekerja sama untuk mengatasi problem kurikulum mereka.

c. Para santri tidak mengidap penyakit ijazah, ini membuktikan ketulusan motivasi mereka dalam belajar agama, maka sebagai hasilnya, atau lebih dapat secara teotitis, mereka akan dapat keridhoan Allah SWT.

d. Selain mengajarkan berbagai ajaran agama, pesantren juga menekankan kesederhanaan, idealisme, persaudaraaan, persamaan di hadapan Tuhan, rasa percaya diri dan bahkan keberanian hidup: dan

e. Para alumni pesantren-pesantren tidak berkeinginan menduduki jabatan-jabatan kepemerintahan, dan karenanya hampir tidak dapat di kuasai oleh pengusaha. ${ }^{20}$

Memperhatikan karakteristik yang unik, ada pada pondok pesantren tidak terlepas dari kelebihan dan kekurangannya. Kelebihannya; semangat atau motivasi belajar yang tinggi karena mereka tidak membutuhkan ijazah, juga mampu bekerja sama dalam segala hal, demikian pula akrabnya hubungan antara santri dengan kiai. Sedangkan kekurangannya adalah sesungguhnya alumni pesantren umumnya kurang memiliki rasa percaya diri dan wawasan sempit. Mungkin hal ini

19 Yulus, Kamus Baru Bahasa Indonesia Usaha Nasional (Surabaya: 1984), 24.

20 Amin Rais, Cakra Wala Antara Cita dan Fakta (Bandung: Mizan, 1989), 162.

$244 \mid$ JURNAL LISAN AL-HAL 
dipengaruhi oleh doktrinitas sehingga lembaganya harus menerima apa yang ia terima. ${ }^{21}$ Dari pemaparan tersebut di atas, maka ada beberapa sistem pendidikan dan pengajaran pondok pesantren:

Pertama, Sistem Pendidikan dan Pengajajaran yang Bersifat Tradisional. Sistem tradisional adalah berangkat dari pola pengajaran yang sangat sederhana, yang dikaji berupa kitab-kitab agama yang ditulis oleh para ulama' pada zaman terdahulu yakni abad pertengahan yang disebut "kitab kuning". Pada sejarah perkembangannya pondok pesantren ini memiliki sistem pendidikan dan pengajaran non-klasikal yakni model sistem pendidikan dengan metode pengajaran weton dan sorogan, metode serupa di jawa barat disebut Badungan, sedangkan di sumatera di pakai istilah halaqah, adapun hal dimaksud sebagaimana berikut:

1) Wetonan. Asal mula perkataan Weton berasal dari bahasa jawa "Weton" artinya adalah waktu, disebut weton karena pelajarannya diberikan pada waktu tertentu, misalnya waktu setelah shalat shubuh atau sehabis dhuhur.22 Pada pelaksanaannya dengan jalan seorang kyai membaca suatu kitab dalam waktu tertentu dan santri membawa kitab yang sama, mendengarkan, dan menyimak bacaan kiai. Dalam system pengajaran ini tidak mengenal terhadap absensi dan santri boleh datang dan boleh tidak dan juga tidak ada ujian. ${ }^{23}$

2) Bandongan. System pengajaran yang serangkaian dengan system sorogan dan wetonan adalah bandongan yang dilakukan saling kaitmengkait dengan yang sebelumnya. system bandongan, seorang santri tidak harus menunjukkan bahwa ia mengerti pelajaran yang sedang dihadapi. Para kyai biasanya membaca dan menterjemahkan kata-kata yang mudah. ${ }^{24}$

3) Sorogan. Asal mula perkataan sorogan berasal dari bahasa jawa, "sorog" yang berarti mendorong, disebut sorogan karena santri-santri yang mau belajar mendorongkan kitabnya dihadapan kyai/guru. Pada pelaksanaannya santri yang cukup pandai mensorogkan sebuah kitab kepada sang kiai untuk dibaca dihadapannya, dan kalau ada salahnya maka kesalahan tersebut langsung dibetulkan oleh kiainya. Cara ini

${ }^{21}$ Departemen Agama RI, Pondok Pesantren dan Sistem Pendidikan NasPional, 8.

22 Yulus, Kamus Baru, 24.

23 Amin Hamzah Wirjo Sukarto, Pembaharuan Pendidikan dan Pengajaran Islam (Jakarta: Muria Office, 1990), 27.

${ }^{24}$ Zamakhsyari Dhofier, Tradisi Pesantren, 30. 
biasa dikatakan sebagai belajar mengaji secara individual. ${ }^{25}$

Menurut Zamarkhsyari Dhofier, "Sistem sorogan terbukti sangat efektif sebagai taraf pertama bagi seorang murid yang bercita-cita menjadi seorang alim". ${ }^{26}$ Sebab menurutnya, sistem ini memungkinkan seorang guru mengawasi, menilai dan membimbing secara maksimal kemampuan seorang murid dalam mengusai bahasa arab.

Kedua, Sistem Pendidikan dan Pengajaran yang Bersifat Modern. Dalam sistem pendidikan dan pengajaran ini terdapat ciri khas tertentu yang diantaranya yaitu:

1) Sistem klasikal. Pola penerapan sistem klasikal ini adalah dengan pendirian sekolah-sekolah baik kelompok yang mengelola pengajaran agama maupun ilmu yang dimasukkan dalam kategori umum dalam arti termasuk di dalam disiplin ilmu- ilmu, (Ijtihadi-hasil perolehan manusia) yang berbeda dengan agama yang sifatnya "taufiqi" (dalam arti kata langsung ditetapkan bentuk dan wujud ajarannya). Kedua disiplin ilmu itu didalam sistem persekolahan diajarkan berdasarkan kurikulum yang telah baku dari Departemen Pendidikan. Bentukbentuk lembaga yang dikembangkan didalam pondok pesantren terdiri dari dua Departemen yang lebih banyak mengelola bidang pendidikan dan kebudayaan dan Departemen Agama.

2) Sistem pelatihan. Pola pelatihan yang dikembangkan oleh Pesantren menumbuhkan kemampuan praktis para santri: pelatihan pertukangan, perkebunan, perikanan, manajemen koprasi dan kerajinan-kerajinan yang mendukung terciptanya kemandirian Integratif. Atas dasar pembentukan kemandirian itu maka sistem pendidikan dan pengajaran pondok pesantren adalah sistem terpadu. Wujud sistem terpadu pondok pesantren terbentuk dari tiga kelompok, diantaranya: (1) Belajar yakni mempelajari jenis-jenis ilmu baik yang berkaitan dengan ilmu umum dan ajaran agama yang kemudian dipraktikkan dalam kehidupan sehari-hari. (2) Pembinaan, yang dilakukan dalam masjid sebagai wadah pengisi Rohani. (3) Praktik, maksudnya mempraktikkan segala jenis-jenis ilmu pengetahuan dan teknologi yang diperoleh selama belajar dan adanya pembinaan yang dilakukan dalam masjid memungkinkan untuk memanifestasikan dalam pondok. ${ }^{27}$

25 A. Aziz Masyhuri, Pokok Pikiran Tentang Pengembangan Pengajian Kitab/Program Tahassus, (Tebuireng: No. 5, 1987), 38.

26 Zamarkhsyari Dhofier, Tradisi Pesantren, 29.

27 Ghazali, Bahri. Pesantren Berwawasan Lingkungan (Jakarta: CV Prasasti, 2003), 30-35.

246 JURNAL LISAN AL-HAL 


\section{c. Tujuan Pendidikan Pondok Pesantren}

Tujuan dalam pendidikan pesantren bukanlah mengejar kepentingan kekuasaan, uang, keagungan duniawi, melainkan juga belajar adalah semata-mata merupakan kewajiban dan pengabdian kepada Allah SWT. Secara umum ciri-ciri dominan dalam pendidikan pondok pesantren adalah kemandirian, life skill, dan hanya kepada Allah SWT. menggantungkan dan berserah diri. Para kyai pondok pesantren sangat menaruh perhatian kepada pengembangan watak individu sesuai dengan karakteristik potensi yang dimiliki. ${ }^{28}$

Seiring dengan perkembangan zaman dan tuntutan masyarakat yang semakin kompleks terhadap pendidikan pesantren, menurut Mukti Ali $^{29}$, pesantren perlu mengadakan pembaharuan pada sistem pendidikan dan pengajarannya dalam rangaka merealisasikan tujuan pendidikan pondok pesantren dan menghadapi tuntutan masyarakat serta perkembangan informasi dan teknologi yang ditandai dnegan globalisai dan modernisasi.

Modernisasi yang dilaksanakan di dunia pesantren memilki karakteristik tersendiri bila dibandingkan dengan pembaharuan lainnya. Keunikannya terletak pada tarikmenarik antara sifat dasar pesantren yang tradisional dengan potensi dasar modernisasi yang progresif dan senantiasa berubah ${ }^{30}$. Modernisasi pesantren dimaknai sebagai uapaya pembaharuan di pondok pesantren dalam rangka menjawab tuntutan masyarakat yang semakin kompleks terhadap pesantren.

Pesantren sebagai lembaga pendidikan yang menyiapkan generasi penerus bangsa yang berkarakter harus terus mendapat perhatian, karena karakter yang baik tidak terbentuk secara otomatis (good characte is not formed automatically), akan tetapi butuh proses panjang. Ini dilakukan untuk mempersiapkan tantangan global dan daya saing bangsa ${ }^{31}$. Memang tidak mudah utuk menghasilkan generasi penerus bangsa dalam hal ini peserta didik yang unggul, tangguh, kreatif dan beradab sebagaimana tertuang dalam undang-undang tersebut. Persoalnnya adalah hingga saat inibangsa Indonesia masih belum mencerminkan cita-cita pendidikan yang diharapkan.

28 Martin Van Bruinessen, Kitab Kuning, Pesantren dan Tarekat, (Yogyakarta: Gading Publishing, 2012), 85.

${ }^{29}$ Minnah El Widdah, dkk, Kepemimpinan Berbasis Nilai dan Pengembangan Mutu Madrasah, (Bandung: Alfabeta, 2012), 11.

30 Abudin Nata, Sejarah Pertumbuhan dan Perkembangan Lembaga Pendidikan Islam, (Jakarta: Grasindo, 2001), 150.

31 Einata Sairin, Pendidikan yang Mendidik, (Jakarta: Yudhistira, 2001), 211. 
Untuk menjawab tantangan di atas tersebut, maka pesantren sudah saatnya menetukan arah pengembangannya. Setidknya kualitas/mutu dijdikan sebagai "paradigma" dalam menjalankan seluruh aktivitas organisasi di pondok pesantren, sehingga seluruh civitas pesantren memiliki kometmen yang tinggi terhadap mutu. Dalam rangka mendesain mutu pendidikan di pondok pesantren, agar supaya sesuai dengan harapan semua pihak dan sesuai dengan yang distandarkan, maka setidaknya pendapat Juran tentang strategi peningkatan mutu pendidikan melalui 10 langkah atau Ten Step to Quality Improvement layak untuk diterapkan dalam pengelolaan manajemen mutu pesantren.

Langkah-langkah tersebut antara lain adalah sebagai berikut: 1) Create awarenness o the need and opportunity improvement, (membentuk kesadaran terhadap kebutuhan dan kesematan untuk melakukan perbaikan), 2) Set goals for improvement, (menetapkan tujuan untuk perbaikan), 3) Organise to reach the goals (mengorganisasian untuk mencapai tujuan), 4) Provide training thoroughout the organization (memberikan atau menyediakan peltihan bagi organisasi), 5) Carry out projects to solve problems (melaksanakan proyek yang ditujukan untuk pemecahan msalah), 6) Report progress (melaporkan perkembangan/ kemajuan), 7) Give recognition (berikan pengakuan/penghargaan), 8) Communicate results (mengkomuniksikan hasil-hasil yang dicapai), 9) Keep score (mempertahankan hasil yang dicapai) dan 10). Maintain momentum by making annual improvement part of the regular systems and processes of the company (memelihara momentum denagn melakukan perbaikan dalam sistem regulasi perusahaan) ${ }^{32}$.

\section{Total Quality Service}

Bagi setiap institusi, khususnya lembaga pendidikan pesantren, mutu adalah agenda utama dan meningkatkan mutu merupakan tugas yang paling penting. Walaupun demikian, ada yang sebagian menganggap mutu sebagai konsep yang penuh dengan teka-teki. ${ }^{33}$ Mutu dianggap sebagai suatu hal yang membingungkan dan sulit untuk diukur. Mutu dapat dikatkan ada apabila sebuah layanan memenuhi spesifikasi yang

32 Mohammed Ahmed Hamadtu Ahmed, Strategic Quality Management in the Arab Higher Education Institutes : A Descriptive and Analytical study, dalam International Journal of Bussiness and Social Science, Vol. 3 No. 24 Desember 2012, 95.

${ }^{33}$ Edward Sallis, Total Quality Management in Education : Manajemen Mutu Terpadu Pendidikan (Peran Strategis Pendidikan di era Globalisasi Modern), (Yogyakarta:IRCiSod, 2006), 29.

248 JURNAL LISAN AL-HAL 
ada. Mutu atau kualitas merupakan sebuah cara yang menentukan, apakah produk trakhir sesuai dengan standar atau belum. ${ }^{34}$

Dalam mendefinisikan tentang mutu atau kualitas ini, ada beberapa pendapat. Diantaranya adalah Crosby 35 berpendapat, kualitas adalah comformance to requere-ment, yaitu sesuai yang diisyaratkan atau distandarkan. Suatu produk memilki kualitas apabila sesuai dengan standar kualitas yanf telah ditentukan. Standar kualitas meliputi bahan baku, proses produksi dan produksi jadi. Menurut pendapat Garvin sebagaimana yang dikutip oleh M.N. Nasution, ${ }^{36}$ kualitas adalah suatu kondisi dinamis yang berhubungan dengan produk, manusia atau tenaga kerja, proses dan tugas, serta lingkungan yang memenuhi atau melebihi harapan pelanggan atau konsumen. Selera atau harapan konsumen pada suatu produk selalu berubah sehingga kualitas produk juga harus berubah atau disesuaikan. Dengan perubahan kualitas produk tersebut, diperlukan perubahan atau peningkatan keterampilan tenaga kerja, perubahan proses produksi dan tugas serta perubahan lingkungan perusahaan agar produk dapat memenuhi atau melebihi harapan konsumen.

Service atau pelayanan dimaknai sebagai bentuk aktivitas yang diberikan oleh satu pihak atau lebih kepada pihak lain dengantujuan untuk memberikan kepuasan kepada pihak kedua yang bersangkutan atas barang dan jasa yang diberikan. Menurut Kotler ${ }^{37}$ pelayanan sebagai suatu tindakan atau kegiatan yang dapat ditawrkan oleh suatu pihak kepada pihak lain, yang pada dasrnya berwujud dan tidak mengakbatkan kepemilikan apapun. Sedangkan hal yang menyangkut pelayanan yaitu; faktor manusia yang melayani, alat atau fasilitas yang digunakan untuk menverikan pelayanan, mekanisme kerja yang digunakan dan bahkan sikap masing-masing orang memberi pelayanan dan yang dilayani.

Quality Service atau kualitas layanan harus dimulai dari kebutuhan pelanggan dan berakhir dengan kepuasan serta pesepsi yang positif terhadap kualitas jasa. Hal ini disebabkan karena kualitas layanan dapat mempengaruhi terhadap loyalitas pelanggan secara langsung maupun tidak langsung melalui tingkat kepuasan mereka. Kualitas layanan akan mendorong pelanggan umtuk memiliki kometmen kepada produk atau layanan yang diberikan oleh suatu organisasi sehingga berdampak kepada

34 Ibid, 53.

35 Philip, B. Crosby, Quality is Free (New York: Mc. Graw Hill Book, Inc, 1979), 58.

36 M.N. Nasution, Manajemen Mutu Terpadu : Total Quality Managemen, (Bogor: Ghalia Indonesia, 2004), 03.

37 Philip Kotler, Manajemen Pemasaran di Indonesia: Analisis Perencanaan, Implementasi, dan Pengendalian, (Jakarta: Selemba Empat, 2002), 83. 
peningkatan market share suatu produk/layanan.

Total Quality Service dimaknai sebagai sistem manajemen strategi dan intergratif yang melibatkan semua manajer dan karyawan, seta menggunakan metode-metode kualitatif dan kuantitati untuk memperbaiki organisasi secara berkesinambungan agar dapat memenuhi ekspektasi pelanggan. Dalam perakteknya, menurut Feliks, "total quality service focuses on five areas, namely: 1. costumer focus; 2. Total involvement; 3. Measurement; 4. Systematic support, and 5. Continous improvement"38.

Melalui lima fokus tersebut, setidaaknya ada dimensi pokok kualitas jasa yang harus dimilki oleh organisasi, di antaranya adalah Realiblitas (reliability) ${ }^{39}$, meliputi dua aspek utama, yaitu konsistensi kinerja (performance) dan siffat yang dapat dipercaya (depandability). Melalui konsep total quality service, diharapkan lembaga pendidikan di pondok pesantren mampu meningkatkan mutu daya saing dan daya jualnya di tengah maraknya persaingan dan globalisasi. Dengan tingginya tingkat persaingan, menyebabkan pelanggan menghadapi lebih banyak alternatif produk/layanan, harga dan kualitas yang bervariasi, sehingga pelanggan akan selalu mencari nilai yang dianggap paling tinggi dari beberapa produk. Kualitas yang rendah akan menimbulkan ketidakpuasan pada pelanggan, tidak hanya pada pelanggan itu saja, tapi juga berdampak pada orang lain.

\section{Meningkatkan Mutu Pendidikan Pesantren Melalui Total Quality Service}

Di dalam pendidikan pondok pesantren, mutu mengacu pada input, process, out put dan dampak. Untuk mengetahui mutu input dapat diihat dari beberapa aspek; Pertama, situasi dan kondisi baik dan tidaknya sumber daya manusia, seperti guru/asatidz, pengurus pesantren, dan santri. Kedua, memenuhi atau tidaknya kriteria input berupa perangkat lunak seperti peraturan dan struktur organisasi di pondok pesantren. Ketiga, mutu in put yang bersifat harapan dan kebutuhan, seperti visi, misi, dan cita-cita.

38 Feliks Anggia Binsar Kristian P., Hotman Panjaitan, Analisys of Customer Loyalty thorough Total Qquality Service, Customer Relationship Management and Customer Satisaction, dalam International Journal of Evaluation and Research inEducation (IJERE) Vol 3, No.3, September 2014 ISSN: 2252-8822, 143.

39 Prabha Rmseook-Munhurrun, Soolakshna D. Lukea_Bhiwajee, Perunjodi Naidoo, Service Quality In The Public Service, Dalam International Journal Of Management And Marketing Research, Volume , Number 1, 2010, 39.

250 JURNAL LISAN AL-HAL 
Total Quality Service yang diterapkan pondok pesantren harus dimulai dengan perubahan budaya organisasi dalam tubuh pesantren. Dengan kata lain, diperlukan pergeseran paradigma dan pola pikir dalam memanage dan mengelola lembaga pendidikan pesantren, mulai dari hal biasa menjadi luar biasa dalam aspek perubahan pada struktur, tanggungjawab, prosedur, proses dan sumber daya fi pondok pesantren. Peningkatan mutu di pepondok pesantren dalam perspektif Total Quality Servive dilakukan dengan cara sebagai berikut:

\section{Costumer focus (fokus pada pelanggan)}

Pelanggan dalam perspektif total quality service di pindok pesantren memiliki peranan yang sangat penting sekali, baik pelanggan internal maupun eksternal (santri, wali santri, alumni, simpatisan dan pengguna lulusan). Dalam mengelola mutu pendidikan di pondok pesantren, pelanggan merupakan kunci untuk meraih keuntungan. Keberlangsungan hidup suatu organisasi sangat ditentukan bagaimanan pandangan pelanggan terhadap organisasi tersebut.

Dalam perpektif ini, santri sebagai konsumen dan investor bagi masa depannya ${ }^{40}$, memiliki peran yang sangat besar dalam menentukan keberlanjutan pendidikannya. Sebagai konsumen santri berhak atas mutu dan pelayanan pendidikan yang berkualitas. Sebagai investor santri berhak mendapat keuntungan masa depan atas pengajaran dan pendidikan yang diperolehnya. Keberhasilan untuk mewujudkan harapan santri merupakann indikator keberhasilan pondok pesantren, yaitu adanya sistem yang bekerja secara dinamis untuk menghasilkan lulusan dengan penempatan yang efektif, menjamin kualitas intruksional dan penunjang kegiatan akademik serta menjamin hubungan baik antara pihak pesantren dengan wali santri.

Misi utama lembaga pendidikan pesantren dalam perpektif total quality service adalah memenuhi kebutuhan dan keinginan pelanggannya dan memiliki obsesi terhadap mutu. Mereka mengakui bahwa pertumbuhan dan perkembangan sebuah institusi bersumber dari kesesuaian layanan institusi dengan kebutuhan pelanggan. Mutu harus sesuai dengan harapan dan keinginan pelanggan bukan merupakan apa yang terbaik bagi mereka menurut instutusi. ${ }^{41}$

${ }^{40}$ Ramon Gunanta, Pendekatan Blanced Scorecard Sebagai peniaian Kinerja pada Institusi Sekolah, fakutas Ekonomi, Universitas Widyatama, 2012, 277.

${ }^{41}$ Edward Sallis, Total Quality Management in Education (Manajemen Mutu Pendidikan), (Yogyakarta:IRCiSod, 2006), 82. 
Pelayanan perlu menjadi subtansi utama dalam sistem manajemen mutu di pondok pesantren, karena semaikin tinggi nilai yang diberikan (pelayanan), maka semakin besar pula kepuaasan pelanggan. ${ }^{42}$ Lembaga pendidikan pesantren harus berusaha untuk memahami dan mengerti apa yang menjadi kemauan dari costumer. Dalam mperpektif ini, lembaga pesantren melakukan identifikasi pelanggan dengan segmen pasar yang akan dimasuki, dengan cara mengelompokkan ukuran perpekytif pelanggan, yang meliputi; 1) pangsa pasar, 2) akuisi pelanggan, 3) kepuasan pelanggan, 4) prfitabilitas pelanggan. Kelompok kedua merupakan faktor pendorong kinerja-pembeda (differentiator),- hasil pelanggan. ${ }^{43}$

\section{Total Involvement (Keterlibatan Secara Total)}

Keterlibatan seluruh komponen pesantren dalam perpektif total qualitys service memiliki peranan yang sangat penting, khususnya dalam menggerakkan seluruh komponen pesantren secara bersama-sama dalam mencapai tujuan organisasi. Keterlibatan seluruh komponen pesantren akan terwujud manakala sistem kepemimpinan dan manajemen di pondok pesantren memberikan akses dan memberdayakan bawahannya untuk memberikan ide, gagasan, masukan segar terhadap kemajuan pesantren. Melaui ide, gagasan, dan masukan yang bervariasi akan melahirkan suatu perencanaan, strategi implementasi dan evaluasi yang harus dilakukan secara bersama-sama, sehingga akan memacu orang-orang yang ada di pondok pesantren untuk lebih aktif dalam mencapai tujuan yang diinginkan.

Usaha melibatkan seluruh komponen pesantren membawa dua manfaat; pertama, didapatkannya suatu keputusan tentang perencanaan, pengorganisasian, pengimplementasian dan evaluasi bagi pengembangan pesantren yang didapatkan dari berbagai pandangan dan pemikiran yang berbeda sebagai bagian dari dinamika organisasi, kedua, keterlibatan seluruh komponen pesantren dalam setiap aktivitas organisasi akan meningkatkan "rasa memiliki" dan tanggungjawab atas keputusan dengan melibatkan orang-orang yang harus melaksanakan. ${ }^{44}$ Melalui pemberdayaan dan pelibatan seluruh komponen pesantren akan

42 Fandy Tjiptono \& Anastia Diana, Total Quality Manajemen, (Yogyakarta: Andi, 2003), 14-15.

43 Veitzhal Rivai \& Ella Juvani Sagala, Manajemen Sumber Daya ManusiaUntuk Perusajhaan, (Jakarta: PT. Raja Wali Grafindo Pesrsada, 2011), 615.

${ }^{44}$ MN. Nasution, Manajemen Mutu Terpadu : Total Quality Management, 20.

252 JURNAL LISAN AL-HAL 
melahirkan keunggulan kompetetif (competetive advantage) bagi pondok pesantren, sehingga memiliki nilai tawar dan nilai jual di tengah perasaingan dunia pendidikan Islam dan pesaingan global. Pelibatan akan berarti, apabila hal tersebut merupakan suatu usaha yang dilakukan secara sistematis untuk membantu organisasi guna meningkatkan nilai yang akan diberikan kepada pelanggan.

Dalam total involvement harus menjalankan prinsip dan konsep sebagai berikut: pertama, mutu merupakan tanggungjawab setiap oraang yang ada pada setiap organisasi, kedua, sasaran mutu melibatakan seluruh tingkat dan setiap orang, ketiga, pelatihan merupakan sarana berkomunikasi, keempat, setiap individu yang dilibatkan harus sesuai dengan kemampuannya, kelima, komunikasi. Proses komunikasi yang dikembangkan di pondok pesantren dalam perpektif total quality service ini setidaknya dilakukan melalui dua jalur, pertama, komunikasi yang dibangun antara pihak pesantren dengan masyarakat di dalamnya (santri, asatidz, pengurus pesantren, wali santri dan alumni), kedua, komunikasi yang dilakukan dengan masyarakat luar pesantren (simpatisan, stakeholders, pengguna lulusan). Oleh karena itu, seluruh komponen pesantren harus bekerja sama dengan masyarakat. Tugas pesantren adalah bagaimana menumbuhkan rasa ikut memiliki (sense of belonging), rasa ikut bertanggungjawab (sense of responsibility) masyarakat terhadap keberlangsungan dan kemajuan pendidikan pondok pesantren. ${ }^{45}$

\section{Measurement (Pengukuran)}

Salah satu tujuan dari suatu tindakan atau aktivitas organisasi di pondok pesantren harus jelas. Dalam total quaity service, mensyaratkan pondok pesantren untuk menetapkan tujuan (sasaran mutu), termasuk sasaran lainnya yang diperlukan untuk mencapai kesesuaian antara harapan dan kenyataan sebagai bahan pengukuran. Sasaran mutu harus dibuat secrara spesifik dan sejalan dengan kebijakan mutu. Sasaran mutu perlu ditetapkan, agar pengukuran dan evaluasi keberhasilan dapat dilakukan guna menindaklanjuti melalui perbaikan. Dalam menetapkan sasaran mutu, maka lembaga pendidikan pondok pesantren hendaknya menggunakan prinsip "SMART"46 :
S (Spesific)
: sasaran harus jelas dan spesifik
M (Measurable) : sasarn harus dapat diukur

45 Daryanto, Administrasi Pendidikan, (Jakarta: Rineka Cipta, 2011), 72.

46 C. Rudy Prihantoro, Konsep Pengendalian Mutu, (Bandung: PT Remaja Rosdakarya, 2012), 50. 
A (Attainable) : sasaran harus realistis dan mungkin dicapai

$\mathrm{R}$ (Reasonable) : harus ada alasan terhadap pemilihan sasaran

$\mathrm{T}$ (Time) : sasaran harus dicapai dalam wwaktu yang ditentukan

Sebagai lembaga pendidikan non profit, measurement (pemgukuran) terhadap keberhasilan program pendidikan di pondok pesantren berbeda dengan pengukuran yang dilakukan pada dunia industri. Evaluasi merupakan tahap terakhir setelah tahap-tahap peneltian, perencanaan dan penggiatan yang dilaksanakan oleh suatu organisasi. $^{47}$

Mengadakan penilaian meliputi dua langkah tersebut, yaitu mengukur dan menilai. ${ }^{48}$ Adapun unsur-unsur pokok dalam suatu evaluasi yaitu: adanya obyek yang mau dievaluasi, adanya tujuan pelaksanaan evaluasi, adanya alat pengukuran, (standar pengukuran/perbandingan), adanya hasil evaluasi apakah bersiffat kualitatif amupun kuantitatif. ${ }^{49}$ Kualitatif artinya, hasil tersebut tidak bisa diukur secara statistik, melainkan diukur melalui pengalaman dan perbandingan nyata. Sedangkan kuantitatif maksudnya adalah hasil dalam suatu pelaksanaan evaluasi dapat diukur berdasarkan angka-angka atau statistik. ${ }^{50}$

Sistem pengukuran sebagai bagian dari sistem evaluasi manajerial di pondok pesantren sangatlah sederhana. Dalam perpekti total quality service, sistem evaluasi pada lembaga pendidikan di pondok pesantren difokuskan pada ketercapaian mutu input, process, out put dan out came yang telah distandarkan oleh pondok pesantren.

\section{Systematic Support (Dukungan yang Sistematis)}

Dalam mengelola pendidikan pesantren dalam perpektif total quality service, dukungan memiliki peran penting dalam rangka pencapaian tujuan organisasi. Tanpa adanya dukungan internal ataupun ekternal, pesantren akan mengalami kesulitan dalam memenuhui kebutuhan organisasinya. Dukungan yang sistematis yang datang dari inetrnal maupun ekternal pesantren akan bermunculan, manakala sistem kepemimpinan di pesantren dilakukan secara terbuka. Artinya pimpinan

47 Onong Uchjana Effendy, Human Relation dan Public Relation, (Bandung: Mandar Maju, 1993), 131.

48 Suharismi Arikonto, Dasar-dasar Evaluasi Pendidikan, (Jakarta: Bumi Aksara, 2001), 3.

${ }^{49}$ M. Chabib Thoha, Teknik Evaluasi Pendidikan, (Jakarta: Rajawali Pres, 1991), 30.

50 Frank Jefkins, Public Relation, (Jakarta : Erlangga, 1992), 157.

$254 \mid$ JURNAL LISAN AL-HAL 
pondok pesantren membuka "kran" terhadap berbagai ide, gagasan, kritik sebagai bentuk perbaikan berkelanjutan yang berorientasi kepada kepuasan pelanggan. Terkait dengan sistem kepemimpinan di pondok pesantren, Hessey and Blancharad melaui teori kontinumnya memberikan konsep tentang bagaimana seharusnya pemimpin pesantren (kyai) memfokuskan dirinya kepada tugas dan tanggung jawabnya serta berfokus pada bagaimana menciptakan hubungan yang baik dengan pengikutnya. ${ }^{51}$

Dari berbagai ide, gagasan dan kritik tersebut, maka dukungan untuk memenuhi kebutuhan pesantren akan bermunculan sebagai akibat dari open management yang diterapkan dalam sistem tata kelola pesantren. Melaui dukungan yang sistematis dari seluruh komponen pesantren, maka akan memberikan akses besar kepada pesantren untuk mencapai tujuan yang telah ditetapkan secara bersama. Dukungan yang kuat dari semua elemen pesantren akan memepermudah dalam pencapaian tujuan yang telah ditetapkan. ${ }^{52}$

\section{Continuous Improvement (Perbaikan Berkelanjutan)}

Continuous improvement merupakan perbaikan berkelanjutan yang harus dilakukan oleh pondok pesantren dalam menciptakan kemajuan organisasi yang lebih baik atau unggul. Perbaikan berkelanjutan merupakan unsur penting fundamental dari penerapan total quality service di pondok pesantren yang dilakukan secara bersamasama (quality improvement team $)^{53}$. Konsep ini diterapkan baik terhadap proses, produk maupun orang yang sedang melaksanakan perbaikan itu sendiri.

Konsep ini dibentuk berdasarkan pada urutan dan langkah-langkah kegiatan yang telah direncanakan pada renstra (rencana strategis) pondok pesantren berkaitan dengan orientasi hasil output seperti produk berupa barang dan jasa. Tujuan utama dari perbaikan berkelanjutan yang

51 The continoum represented the extand that the leader focuses on the required taks or focuses on their relations with their followers. Originally developed by Hessey and Blanchard (1969, 1979, 1996). Lihat dalam Jim Allen McCleskey, Situasional, Transformational, and Transactional Leadership and Leadership Development, dalam Journal of Business Studies Quartterly 2014, Volume 5, Number 4 ISSN 2152-1034, 118.

52 Hasan Baharun, Manajemen Mutu Pendidikan Pesantren dalam Perspektif Total Qquality Service, dalam Journal Afkarina, Volume 2 Nomor 6, Maret-Agustus 2016, 66.

${ }^{53}$ The quality improvement team merupakan salah satu konsep Crosby's Fourteen Steps. Lihat Dilip KumarAdhwarjee et al, Exploring Crosby's Ffourteen Steps to Quality Improvement Appliead to Industry, dalam (IJITR) International Journal of Innovative Technology And Research, Volume No.1 Issue No. 6, Oktober-November 2013, 544. 
diterapkan dalam sistem manajemen pesantren adalah proses yang handal.

Dengan demikian, untuk menciptakan lembaga pendidikan pesantren yang berorientasi pada countinous improvement dalam perspektif total qulaity service, maka diperlukan kometmen terhadap kualitas yang harus diabangun dan melekat pada setiap individu, dengan pemahaman bahwa: Pertama, kualitas merupakan kunci utama dalam pencapaian tujuan organisasi. Minimnya perhatian terhadap kualitas suatu proses dan produk/jasa akan mengakibatkan kegagalan jangka panjang dalam pengelolaan pesantren. Kedua, perbaikan mutu pendidikan di pondok pesantren menurut kometmen secara totalitas bagi seluruh komponen pesantren. Kometmen ini harus dibangun dan dijadikan sebagai budaya bagi pengembangan lembaga pendidikan pesantren yang kompetetif dan berdaya jual tinggi. Ketiga, perbaikan kualitas di pondok pesantren menuntut banyak tenaga, waktu, biaya dan diperlukan pembinaan dan pelatihan. Keempat, perbaikan kualitas menuntut keterlibatan semua komponen pesantren secara aktif, dan kometmen mutlak dari manajemen puncak. ${ }^{54}$

Dari beberapa perspektif Total Qquality Service yang diterapkan di pondok pesantren, berimplikasi pada mutu pendidikan pesantren yang memiliki keunggulan kompetetif (competetive advantage) dengan selalu berorientasi pada kepuasan pelanggan dalam kanca persaingan dan kompleksnya tuntutan masyarakat serta tuntutan global.

\section{E. Simpulan}

Implementasi Total Quality Service dalam lembaga pendidikan pesantren berfokus pada jasa/pelayanan atau produk. Suatu "Service" dikatakan bermutu manakala menyamai bahkan melebihi harapan dari pelanggannya. Dengan demikian mutu suatu jasa maupun barang selalu berorientasi pada kepuasan pelanggan. Lembaga pendidikan pesantren dikatakan bermutu berarti merujuk pada kualitas produk yang dihasilkan oleh pesantren, yang meliputi; banyaknya siswa yang memiliki prestasi baik di bidang kademik maupun di non akademik, adanya dukungan timbal baik antara pesantren "pelanggannya", out put dan out came pesantren sesuai dengan harapan, dan masih banyak lagi. Mutu pendidikan pesantren dalam perspektfi ini, dapat juga dilihat dari dua hal,

54 Ijudin, Pengembangan Konsep Mutu Pendidikan Pondok Pesantren, dalam Jurnal Pendidikan Universitas Garut Fakultas Pendidikan Islam dan Keguruan Universitas Garut ISSN: 1907-932X, 27.

256 JURNAL LISAN AL-HAL 
yaitu mengacu pada proses pendidikan dan hasil pendidikan. Proses pendidikan yang bermutu ditunjukkan oleh keterlibatan seluruh komponen pesantren dalam kegiatan pendidikan. sedangkan hasil pendidikan dapat dilihat dari sejauh mana lulusan pesantren memiliki kompetensi dan kepribadian yang sesuai dengan visi dan misi pesantren, serta sejauh mana kiprah alumni dalam kehidupannya di tengah-tengah masyarakat.

\section{Daftar Pustaka}

Arikunto, Suharsimi, Dasar-dasar Evaluasi Pendidikan, Jakarta: Bumi Aksara, 2001.

Baharuddin, Pengembangan Lembaga Pendidikan Islam, Malang: UIN Maliki Press, 2011.

Baharun, Hasan, Manajemen Mutu Pendidikan Pesantren dalam Perspektif Total Quality Service, dalam Jurnal Afkarina, Volume 2 Nomor 6, Maret-Agustus 2016.

Bruinessen, Martin van, Kitab Kuning, Pesantren dan Tarekat, Yogyakarta: Gading Publishing, 2012.

Bush Tony, Manajemen Mutu Kepemimpinan Pendidikan, Jogjakarta: IRCiSoD, 2012.

Dhofir, Zamakhsyari, Tradisi Pesantren: Studi tentang Pandangan Hidup Kyai, Jakarta: LP3ES. 1982.

Dina, Indriana, Ragam Alat Bantu Media Pengajaran, Jogjakarta: DIVA Press, 2011.

Efendi, Nur. Manajemen Perubahan di Pondok Pesantren, Yogyakarta:Teras, 2014.

Geertz, Clifford, Abangan Santri, Priyayi dalam Masyarakat Jawa, ter. Aswab Mahasin, Jakarta: Dunia Pustaka Jaya, 1983.

Halim Soebahar, Abd,. Modernisasi pesantren Studi Transfomasi Kepemimpinan Kiai dan Sistem Pendidikan Pesantren. Yogyakarta: LkiS, 2013.

Horikhoshi, Hiroko, Kiyai dan Perubahan Sosial, Jakarta: P3M, 1987.

Madjid, Nurcholis, Bilik-Bilik Pesantren, Jakarta: Paramadina, 2006.

Mansur, Moralitas Pesantren Meneguk Kearifan dan Telaga Kehidupan, Yogyakarta: Safiria Insania Press, 2004.

Mas'ud, Abdurrahman, Intelektual Pesantren: Perhelatan Agama dan 
Tradis. Yogyakarta: LkiS, 2002.

Mastuhu, Dinamika Sistem Pendidikan Pesantren; Suatu Kajian Tentang Unsur dan Nilai Sistem Pendidikan Pesantren, Jakarta: INIS, 1994.

Masyhud, M.Sulton dan Khusnurridlo, Moh., Manajemen Pondok Pesantren, Jakarta: DIVA Pustaka, 2003.

Masyhud, Sulthon, Manajemen Profesi Kependidikan, Jember : LPMPK, 2011.

Qomar, Mujamil, Pesantren dari Tranformasi Metodologi Menuju Demokratisasi Institusi, Jakarta: Erlangga, 1995.

Rahardjo, M. Dawam, Pesantren dan Pembaaruan, Jakarta: LP3ES, 1995.

Rahim, Husni. Arah Baru, Pendidikan Islam di Indonesia, Jakarta: PT. Logos Wahana Ilmu, 2001.

Sallis, Edward, Total Quality Management in Education (Manajemen Mutu Pendidikan), Yogyakarta: IRCiSod, 2006.

Tjiptono, Fandy, \& Anatasia Diana, Total Quality Management, Yogyakarta: Andi, 2003. 